Jurnal Syntax Imperatif: Jurnal Ilmu Sosial dan Pendidikan

p-ISSN: 2721-2491 e-ISSN : 2721-2246

Vol. 1, No. 3, Juli 2020

\title{
Pengaruh Implementasi Kebijakan Sertifikasi Guru Terhadap Kompetensi Pedagogik, Serta Dampaknya Terhadap Kompetensi Profesional Guru Madrasah Ibtidaiyah di Kecamatan Bungusari Kota Tasikmalaya
}

\section{Shopi Guspiati}

Sekolah Tinggi Ilmu Administrasi (STIA) YPPT Priatim Tasikmalaya, Indonesia

E-mail: guspiatishopi@gmail.com

\section{Abstrak}

Penelitian ini dilakukan untuk mengetahui besar kecilnya pengaruh serta mendeskripsikan tentang implementasi kebijakan program sertifikasi guru terhadap kompetensi pedagogik serta berdampak terhadap kompetensi profesinal guru MI di Kecamatan Bungursari Kota Tasikmalaya. Kompetensi pedagogik erat kaitannya dengan keprofesionalan guru, karena guru merupan asset terbesar dalam dunia pendidikan dan ujung tombak dalam membangun dan meningkatkan kualitas sumber daya manusia melalui pendidikan formal, namun kualitas pendidikan saat ini belum memperlihatkan kualitas yang diharapkan. Hal ini disebabkan kurangnya kompetensi guru dalam melaksanakan tugasnnya.Menjawab pertanyaan tersebut perlu adanya peningkatan kompetensi guru baik kompetensi pedagogik maupun professional, yang tentunya diikuti oleh kesejahteraan guru. Program sertifikasi guru merupakan kebijakan pemerintah atas dasar UU no. 14 tahun 2005 tentangkebijakan Guru dan Dosen, dan Permendiknas nomor tentang Sertifikasi Guru dalam Jabatan melalui penilaian portofolio. Dengan kebijakan ini diharapkan para guru dapat meningkatkan kompetensi, guna menghasilnya lulusan yang berkualitas. Penelitian ini, selain deskriptif untuk menggambarkan data apa adanya berdasarkan data yang diperoleh melalui sampel, penelitian ini pun bersifat menerangkan (explanatory), yang bertujuanuntuk menguji tentang adanya hubungan sebab dan akibat antara berbagai variable yang diteliti. Adapun analisis data dalam penelitian yang menggunakan data primer dan sekunder yaitu dengan mengumpulkan data berupa angket atau kuesioner, wawancara, survey dan dokumentasi.Hasil penelitian menunjukkan bahwa guru MI yang berada pada lingkungan Kecamatan Bungursari terkait gagasan kebijakan sertifikasi melalui sub aspek yang berpengaruh besar terhadap kompetensi Pedagogik.

Kata Kunci: Pengaruh Implementasi kebijakan; Sertifikasi Guru; Kompetensi Pedagogik; Kompetensi Profesional;

\section{Pendahuluan}

Pendidikan merupakan institusi yang paling bertanggung jawab terhadap perkembangan suatu bangsa. Didalam institusi pendidikan, guru diharapkan mampu melahirkan sumber daya yang berkualitas secara akademik dan sekaligus mumpuni secara moral sekaligus. Sebab, diakui atau tidak sumber daya siswa didik sangat menentukan dalam meningkatkan suatu kinerja pendidikan di Indonesia.

Pendidikan juga memiliki peran penting terhadap suatu hal dalam meningkatkan kualitas. Peningkatan kualitas pendidikan merupakan suatu proses yang terintrigrasi dengan proses peningkatan kualitas sumber itu sendiri. Hal itu, sejalan dengan UndangUndang RItahun 2003, pasal 3 ayat 6, yang pendidikan diselenggarakan sebagai suatu proses untuk membudayakan serta memperdayakan peserta didik yang berlangsung 
sepanjang hayat. Menyadari pentingnya suatu proses untuk meningkatkan kualitas, maka pemerintah bersama kalangan swasta dan orang tua secara serentak berupaya untuk melalukan berbagai usaha dalam membangun pendidikan yang lebih baik dan berkualitas, diantaranya melalui sesi perkembangan dan perbaikan kurikulum, dan sistem untuk mengevaluasi sarana pendidikan serta peningkatan kualitas pengembangan materi ajar.

Jika memiliki pendidik yang berkualitas serta menjamin untuk mampu bersaing dengan baik, maka diperlukan adanya peningkatan mutu pendidikan bukti keseriusan pemerintah dalam pentingnya meningkatkan kualitas pendidikan yaitu dengan mengeluarkan undang-undang tentang Guru dan dosen. Undang-undang ini memiliki isyarat bahwa guru adalah pendidik profesional dengan menjalankan tugas memberikan ilmu yang bermanfaat serta memberikan pengajaran bahkan bimbingan kepada seluruh siswa didik.

Guru merupakan aset dalam organisasikarena memiliki peranan sebagai tenaga pendidik yang dapatmenghasilkan lulusanterbaik. Salah satu sorotan pendidik yang dikaitkan dengan profesionalisme guru dan upaya pemerintah dengan mengeluarkan kebijakan tentang "Sistem Pendidikan Nasional" dalampelaksanaan Undang-Undang Dasar (UUD) 1945 pasal 31 ayat 3 yakni "Pemerintah mengusahakan dan menyelenggarakan satu sistem pendidikan".

Sebagai tenaga profesional, sedikitnya mempunyai beberapa kemahiran dalam merancang suatu program ajaran seperti melaksanakan beberapa bahanajar yang akan di sampaikan pada siswa dan tentunya mengetahui apa yang siswa kurang tahu dari sebuah pertanyaan.Sebagai guru tidak hanya dituntut untuk menguasai berbagai bidang keilmuan dan bahan ajar saja, melainkan metode yang perlu untuk memotivasi peserta didik, dan memiliki wawasan luas terhadap dunia pendidikan, tetapi memiliki beberapa pemahaman dan pengalaman untuk mengetahui hakikat dari manusia, karena nyatanyadalam melandasi pola pikir dan budaya kerja guru, serta meloyalitaskan terhadap profesi pendidikan

Guru profesional bukan hanya untuk mendidik, mengajar, dan melatih, melainkan perlu adanya program untukmembimbing, sertamengevaluasi para siswa, tetapi juga berkaitan dengan kepribadian yang dapat memicu keberhasilan peserta didik. Kepribadian guru dapat mempengaruhi suasana kelas/sekolah, yaitu kepribadian guru yang dapat memberikan kebebasan dalam mengeluarkan buah pikirannya maupun mengembangkan kreatifitasnya. Namun berbeda dengan kebebasan dengan apa yang mereka peroleh dari atasannya seperti "Kepala Sekolah, Pengawas, Kakanwil, sampai Mendikbud”. Keseluruhannyadapat dipengaruhi dan dibatasidengan diarahkan pada tujuan pendidikan nasional. Salah satu upaya yang dilakukan untuk melaksanakan tujuannya adalah dengan memperbaiki apa yang dilakukan melalui manajemen pendidikan dengan cara meningkatkan kinerja guru, karena tantangan di dunia pendidikan saat ini adalah untuk menghasilkan sumber yang berkualitas dan dapat bersaing di era global. 
Seiring dengan pembaharuan pendidikan di Indonesiadenganmemperbaikitujuan utama pemerintah dengan maksud agar tujuan pendidikan Nasional yaitudengan menghasilkan guru yang berkompetensi dalam bidangnya. Salah satu upaya pemerintah dalammemperbaiki kesejahteraan guru adalah dengan pemberian sertifikasi bagi guru.Yang bertujuan untuk menghasilkan tenagadidik yang berkompeten dalamsuatubidang dan dapatmeningkatkan kesejahteraan guru.

Peraturan-peraturan tersebut, di sisi lain merupakan angin segar bagi para guru yang sudah memenuhi persyaratan sertifikasi, karena berarti peningkatan kesejahteraan para guru, akan tetapi sudah terlalu banyak yang menanti tanggung jawab para guru dalam dengan tugas kesehariannya, yaitu peningkatan kualitas pendidikan dan pembelajaran dalam rangka peningkatan sumber pendidikan.

Program sertifikasi ini dilaksanakan dengan tujuan untuk meningkatkan kompetensi guru sebagai tenaga pendidik yang profesional. Melalui sertifikasi ini guru dituntut untuk bersungguh-sungguh menjalankan tugas sebagai guru dan mengerahkan segala pemikirannya kepada siswa yang di didiknya. Program sertifikasi diberlakukan kepada guru yang memiliki masa kerja minimal 5 tahun dengan usia maksimal 50 tahun (Pendidikan, 2013).

Sertifikasi merupakan bentuk penghargaan atas pencapaiansebuah kinerja yang berkompeten. Dengan sertifikasi yang menuntut para guru untuk dapat melaksanakan kewajibannya sebagai tenaga didik yang professional. Jika para guru kurang memenuhi kewajibannya, maka secara otomatis pemerintah akan memberhentikan tunjangan sertifikasinya. Oleh karena itu sebagai bagian dalam meningkatkan kompetensinya, maka guru maka diharapkan mempunyai pembelajaran pada pendidikan di Indonesia yang menjadi bahan.

Guru yang terdaftardalam kualifikasi pendidikan minimum sudah menginjakan S1 atau diploma empat menguasai empat kompetensi yang harus dimiliki pada masingmasing guru, antara lain kemampuan pedagogik, profesional, soial, dan kepribadian), memiliki sertifikat pendidik, sehat jasmani dan rohani, serta memiliki kemampuan untuk mewujudkan tujuan pendidikan nasional.

\section{Metode Penelitian}

Penelitian ini adalah deskriptif kuantitatif dengan pengkuran skla likert. Metode yang dilakukan dalam penelitian ini adalah metode survey, yaitu metode yang digunakan untuk mendapatkan data dari sekolah dengan dibantu kuesoner yang diberikan kepada responden untuk mendapatkan data yang akan dianalisis (Sugiyono, 2017)

Penelitian ini bersifat menerangkan (explanatory), bertujuan mengujihipotesishipotesis tentang adanya hubungan sebab akibat antara berbagai variable yang diteliti. Adapun variable independent dalam penelitian ini adalah implementasi kebijakan sertifikasi guru, sedangakan variable dependentnya adalah kompetensi pedagogic dan professional. 


\section{Hasil dan Pembahasan}

\section{A. Hasil}

\section{Konsep Implementasi Kebijakan}

Memperhatikan beberapa konsep yang telah dijelaskan, maka yang berada di dalamkajianmerupakan suatu prosesuntuk mengubahsuatu gagasan menjadi tindakan, dan kemungkinan dengancara menjalankan perubahan tersebut. Untuk menganalisi bagaimana implementasi berproses kepada suatu kebijakan, banyak yang ditemukannya dalam beberapa literatur, (parson 1997) membagi bagian dengan memilih secara garis besar untuk menunjuk beberapa model implementasi kebijakan, yaitu dengan model analisis kegagalan, model rasional (top down), model pendekatan bottom-up, teori-teori hasil sintesis.

Implementasi kebijakan publik merupakan beberapa proses kegiatan didalam sebuah program administratif yang dilakukan setelah ditetapkan/disetujui suatu kebijakan. Hubungan implementasi kebijakan dengan tujuan menyatakan bahwa menyatakan kebijakan sebagai suatu tindak anyang dilakukan oleh individu atau kelompok pemerintah maupun swasta yang disarankan untuk mencapai tujuan yang telah ditetapkan dalam keputusan-keputusan sebelumnya.

\section{Sertifikasi Guru}

Sertifikasi Guru dalam Jabatan adalah proses pemerolehan sertifikat pendidik oleh seorang yang telah bertugas pada satuan pendidikan yang dalam merupakan suatu hal dalam binaan Departemen Agama. Sertifikat pendidik berarti bukti formal sebagaiacuan yang diberikan sebagai tenaga profesional.

Berdasarkan Petunjuk dan Pelaksanaan Sertifikasi terhadap Guru dalam Jabatan Tahun 2011 dinyatakan bahwa sertifikasi yang menjabat sebagai guru adalah salah satu upaya untuk meningkatkan kualitas kinerja guru pada satuan pendidikan formal. Selanjutnya dalam Peraturan Menteri Pendidikan Indonesia tentang Sertifikasi Guru Dalam Jabatan pada pasal 1 dinyatakan bahwa sertifikasi Guru dalam Jabatan selanjutnyaadalahdengan proses pemberian sertifikat pendidik kepada guru yang bertugas sebagai guru kelas, guru mata pelajaran, guru bimbingan dan konseling, dan guru yang diangkat jabatannyamenjadi pengawas.

Terpenuhinya syarat-syarat yang telah ditentukan, maka pada pasal 16 ayat 1 menyatakan bahwa pemerintah akan memberikan profesi kepada guru yang telah memiliki sertifikat pendidik dan diankat langsung oleh penyelenggara pendidikan dan satuan pendidikan yang diselenggerakan oleh masyarakat. Ayat 2 berbunyi sebagaimana yang dimaksudkan pada ayat 1 untuk memberikan sebuah tunjangan profesi yang diberikan setara dengan gaji pokok.

Uraian yang telah dikemukakan di atas adalah tampak dengan jelas bahwa sertifikasi sebagai suatu proses untuk memperoleh sertifikat pendidik bagi guru dan dosen, memerlukan berbagai persyaratan, yakni persyaratan akademik (kualifikasi), 
berupa jenjang pendidikan tertentu, serta memiliki tanggung jawab dan kemampuan untuk mewujudkan tujuan pendidikan nasional, kompetensi yang meliputi keprofesionalan, pedagogik, dan kompetensi sosial, yang merupakan persyaratan untuk memperoleh sertifikat pendidik sebagai pengakuan formal bagi seorang guru.

Dalam Undang-Undang RI. Nomor 20 tahun 2003, tentang SISDIKNAS, tujuan pendidikan nasional dapat dilihat dari usaha terencana untuk mewujudkan suasana pembelajaran agar peserta didik mengembangkan potensi dirinya dalam melakukan spiritual keagamaan,serta keterampilan yang dibutuhkan oleh masyarakat, bangsa, dan negara.

Tujuan pendidikan nasional seperti tercermin dalam pengertian pendidikan nasional, nampak bahwa tugas dan tanggung jawab guru cukup besar. Hal ini terkandung dalam dua makna yakni mewujudkan suasana belajar dan proses belajar. Suasana pembelajaran dapatmenciptalan suatu kondisi dan situasi dalam mencakup banyak hal, seperti pengaturan lingkungan belajar, manajemenkelas, pengaturan dan membutuhkan segala pengetahuan dalam proses pengajaran.

Mulyasa menulis bahwa kompetensi guru merupakan perpaduan antara kemampuan, keilmuan, sosial, dan spritual secara kaffah (keseluruhan) membentuk kompetensi standar profesi guru, yang mencakup penguasaan materi, memahami situasi peserta didik, pembelajaran yang mampumendidik perkembangan kepribadian dan keprofesionalan.

\section{B. Pembahasan}

1. Pengaruh Implementasi Kebijakan Seritifikasi Guru MI Ditinjau Dari Aspek Kompetensi Pedagogik

Pengaruh Implementasi kebijakan sertifikasi ditinjau daribeberapakompetensi pedagogik guru Madrasah Ibtidaiyah di Kecamatan Bungursari yang didasarkan pada hasil wawancara, observasi, kuesoner atau angket dan studi dokumentasi yang menunjukan bahwa adanya program kebijakan sertifikasi guru yang memiliki pengaruhsangat baik. Melalui sub aspek mulai dalam mempersiapkan silabus, RPP, strategi termasuk pengkondisian peserta didik sampai pada proses KBM selesei untuk meunjukkan bahwa guru MI yang berada pada lingkungan Kecamatan Bungursari berpengaruh baik.

\section{Pengaruh Implementasi Kebijakan Sertifikasi Guru MI Ditinjau Dari Aspek Kompetensi Profesional}

Pengaruh implemenasi kebijakan sertifikasi guru ditinjau dari aspek kompetensi profesional, berdasarkan hasil pengamatan di lapangan menunjukkan bahwa guru yang disertifikasi mengalami perubahan positif terhadap kompetensi guru dengan kata lain adanya kebijakan sertifikasi guru dalampengaruh baik meskipun sedikit dikarenakan dalam mengembangkan diri dalam proses pembelajaran belum sepenuhnya dapat memanfaatkan TIK hal ini disebabkan sarana prasarana di beberapa madrasah kurang mendukung bahkan tidak memiliki fasilitas tersebut (Haryanto, n.d.). 
Shopi Guspiati

\section{Kesimpulan}

Guru Madrasah Ibtidaiyah di Kecamatan Bungursari yang sudah tersertifikasi mengalami peningkatan dalam mengembangkan kualitasnya sebagai guru, dalam hal ini membuktikan bahwa adanya sertifikasi guru berpengaruh positif terhadap peningkatan kompetensi pedagogik meskipun pengaruh tersebut rendah.

Di tinjau dari aspek kompetensi professional, guru MI di kecamatan Bungursari mengalami perubahan dalam proses kegiatan KBM. Dengan ini menunjukkan bahwa adanya pengaruh baik namun rendah, karena kurangnya guru memanfaatkan TIK dalam mengembangkan dirinya yang disebabkan beberapa faktor kemungkinan tidak adanya fasilitas di madrasahnya, atau ketidakfahaman guru tersebut pada TIK. 


\section{BIBLIOGRAFI}

Haryanto, A. T. (n.d.). IMPLEMENTASI KEBIJAKAN SERTIFIKASI GURU DI KABUPATEN BOYOLALI.

MuIyasa, E. (2007). Standar Kompetensi dan Sertifikasi Guru, Remaja Rosdakarya. Bandung.

Pendidikan, K. (2013). Kebudayaan [Kemdikbud].(2013). Revitalisasi Kearifan Lokal Sebagai Upaya Penguatan Indentitas Keindonesiaan. Diunduh Pada, 19. Saniyah, S. (2008). Motivasi guru dalam mengikuti program sertifikasi guru di Madrasah Aliyah Negeri (MAN) Model Bangkalan. Universitas Islam Negeri Maulana Malik Ibrahim.

Sugiyono, P. D. (2017). Metode Penelitian Pendidikan: Pendekatan Kuantitatif, Kualitatif, R\&D (Cetakan Ke). Bandung: CV Alfabeta. 